\title{
Detailed description of the Ócsa Bird Ringing Station, Hungary
}

\section{Location, methods and overview of results (1984-2015)}

\author{
Tibor CsÖRG0 ${ }^{1 *}$, Andrea Harnos ${ }^{2}$, Lajos Rózsa $^{3}$, Zsolt KARCZA ${ }^{4} \&$ \\ Péter FEHÉRVÁRI ${ }^{2,5}$
}

Received: November 26, 2016 -Accepted: December 14, 2016

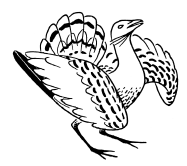

Tibor Csörgő, Andrea Harnos, Lajos Rózsa, Zsolt Karcza \& Péter Fehérvári 2016. Detailed description of the Ócsa Bird Ringing Station, Hungary. - Ornis Hungarica 24(2): 91-108.

exploratory analyses of migration phenology and morphometrics of the most common passerine species at the Ó at the Ocsa Bird Ringing Station. This station is situated in the Ocsa Landscape Protection Area that belongs to the Duna-Ipoly National Park, Hungary. The area is somewhat cooler and more humid than the surrounding agricultural fields and tree plantations, covered by a mosaic of diverse hygrophilous vegetation patches. Bird trapping is mostly based on Japanese mist-net lines crossing different plant communities. During the period of 1984-2015, a total of 422,862 birds were trapped and ringed here, while 202,739 local, 1,235 within country, and 443 foreign recaptures were also recorded. Each bird is characterized by the following data: location and time of capture, species, age, sex, scores of fat, pectoral muscle, wing tip abrasion, and moult, length of wing, $3^{\text {rd }}$ primary, and tail, and body mass. After subjected to a rigorous quality check, digital data are deposited in the archive of the Hungarian Bird Ringing Centre, and the EURING data base. From time to time, other research projects also utilized the accessibility of wild birds captured here, thus collection of blood samples, ecto- and endoparasites was carried out at the station. The relatively long time span, large number of species and individuals, and the readily available environmental (weather, vegetation, etc.) data makes the avian data collected here a suitable base for studies of various disciplines like capture methodology, habitat preferences,breeding, migration, and wintering, effects of weather and climate change, and epidemiology of viruses and parasites.

Keywords: bird banding, Carpathian Basin, long-term data set, standard methodology, migration phenology, morphology, habitat preference, parasite

Összefoglalás Jelen cikk egy olyan cikksorozat bevezetố része, amelyben egy közép-magyarországi gyưrűzőállomáson - Ócsai Madárvártán - leggyakrabban előforduló énekesmadarak vonulás időzítésének és testméreteinek exploratív elemzéseit közöljük. A gyứrűző állomás a Duna-Ipoly Nemzeti Parkhoz tartozó Ócsai Tájvédelmi Körzetben található. A terület egy jégkorszaki maradványláp, mozaikos vegetációval. A madarak befogása a területre jellemző különböző növénytársulásokban, döntő többségben japán típusú függönyhálókkal történik. Az 1984-2015 között zajló munka során 422862 madarat fogtunk, gyưrúztünk, 202739 saját, 1235 hazai és 443 külföldi vonatkozású visszafogásunk volt. A befogott madarakról a következő adatokat vettük fel: a madarak befogási helye 12 méteres pontossággal, ideje 1 órás pontossággal, faja, kora, ivara, zsír-, izom-, vedlés- és kopás kódja, szárny-, 3. evező-, és farokhossza $1 \mathrm{~mm}$-es pontossággal, testtömege $0,1 \mathrm{~g}$ pontossággal, teljes vedlést végző madárnál az evezőés faroktollaknál egyenként 0-5-ös skálán. Az adatok - ellenőrzés után - a Magyar Madárgyưrúzési Központba és az EURING adatbázisba kerülnek. A standard adatfelvételen túl - időközönként és bizonyos fajoknál - egyéb vizsgálatok is történnek, pl. ekto, és endoparazita gyuujtés, vérminta gyújtés stb. A viszonylag hosszú időintervallum, a nagy fajszám és fajonkénti adatszám, a háttéradatok (időjárás, 
vegetáció mintázat) miatt az adatok számos madártani vizsgálatnak lehetnek forrásai, és képezhetnek összehasonlítási alapot más területeken zajló kutatások eredményeivel. A feldolgozás, értelmezés a legkülönbözőbb szempontok alapján történik: fogás-módszertani vizsgálatok, élőhely-preferencia, költés és telelés, vonulás, időjárási hatások, klímaváltozás, parazitológiai és virológiai vizsgálatok stb.

Kulcsszavak: madárgyưrúzés, Kárpát-medence, hosszútávú adatsor, standard módszerek, madárvonulás, morfológia, élőhely-preferencia, parazita

\footnotetext{
${ }^{1}$ Department of Anatomy, Cell- and Developmental Biology, Eötvös Loránd University, 1117 Budapest, Pázmány Péter sétány 1/C, Hungary, e-mail: csorgo@elte.hu

${ }^{2}$ Department of Biomathematics and Informatics, University of Veterinary Medicine, 1078 Budapest, István utca 2., Hungary, e-mail: harnos.andrea@univet.hu

${ }^{3}$ MTA-ELTE-MTM Ecology Research Group, Hungarian Academy of Sciences, 1117 Budapest, Pázmány Péter sétány $1 / C$, Hungary

${ }^{4}$ Hungarian Bird Ringing Center, BirdLife Hungary, 1121 Budapest, Költő utca 21., Hungary

${ }^{5}$ Department of Zoology, Hungarian Natural History Museum, 1088 Budapest, Baross utca 13., Hungary *corresponding author
}

\section{Introduction}

Avian migration research in Hungary dates back to as early as 1908, when this country was the third in the world to adopt and implement a national ringing scheme (Karcza \& Magyar 2009). Organized forms of ringing activities have been carried out continuously since then and today, Hungarian ornithologists are regional leaders in the annual total number of birds ringed. In the last decades, the majority of these birds are captured and marked at Actio Hungarica sites. These sites have common standardized methodologies in trapping and handling birds, adopted from and named after the Actio Baltica system (Busse \& Kania 1970, Busse 1974), and the European-African songbird migration network (Bairlein 1994). Today a total of 8 Actio Hungarica sites operate throughout the country, of which our focal site, the Ócsa Bird Ringing Station (ocsabirdringing.org) has the largest number of cumulative captures. Initial work started here in 1983, when the site was evaluated and chosen for as the location of a ringing station, and the position of the mist net lines were determined. One of the most attractive features of the area - asides from the diverse habitat - is the simple logistics, as it is easily reached from Budapest via public transport or road. Initially, the working staff lived in tents and reed huts through several years. In 2001, a brick building was constructed, considerably improving working and living conditions (electricity, internet connection, drinking water supply, heating, working and sleeping rooms). The building also serves as accommodation for visitors and volunteers, thus attracting more help throughout the season. Today, the ringing station is one of the most visited site from professionals and laymen alike, and serves as an educational facility, provides service for companies and conducts avian population research.

Here we describe in detail the site; the methods applied and present comprehensive results of bird ringing at the station. Our aim is to help evaluate previously and future 


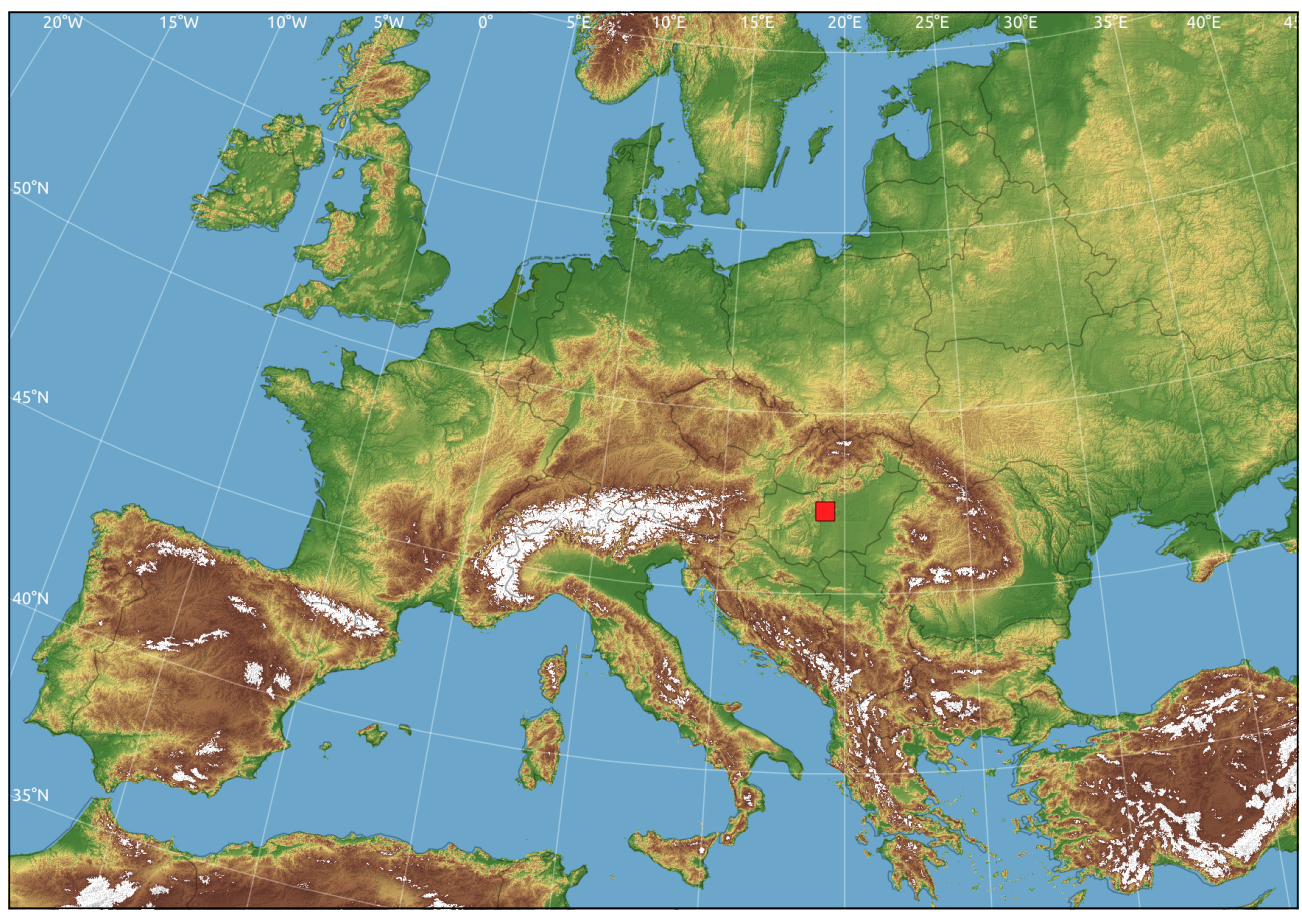

Figure 1. Location of the Ócsa Bird Ringing Station (red square) on a continental scale. The Carpathian montain range is a potential geographical barrier for migrating birds

1. ábra Az Ócsai Madárvárta (piros négyzet) elhelyezkedése kontinentális skálán. A Kárpátok a vonuló madarak számára potenciális akadályt jelentenek

published studies using the data generated at the site and also to fundament a series of future publications that aim to give comprehensive exploratory and descriptive statistics (Harnos et al. 2015b, 2016a) on migration timing and morphology of the most commonly captured species here (e.g. Harnos et al. 2016c,b).

\section{Location}

The ringing station (N47.2970, E19.2104) is situated on the western periphery of the town of Ócsa, Hungary, ca. $33 \mathrm{~km}$ from Budapest. From an avian migrants' perspective the station is in a large, low altitude basin (Carpathian Basin) surrounded by mountain ranges that may act as geographical barriers (Figure 1). Of these, presumably the most important are the Carpathians as they encompass the region from north-west to south-east.

On a smaller spatial scale the station is situated on the edge of a wetland in the Ócsa Landscape Protection Area of the Duna-Ipoly National Park (Figure 2). The wetlands here are one of the very few remaining post-glacial peat bogs in the Carpathian Basin. Their conservation value was recognized as early as 1978, when the area was declared protected. Furthermore, the area represents the only natural type habitat in the larger 


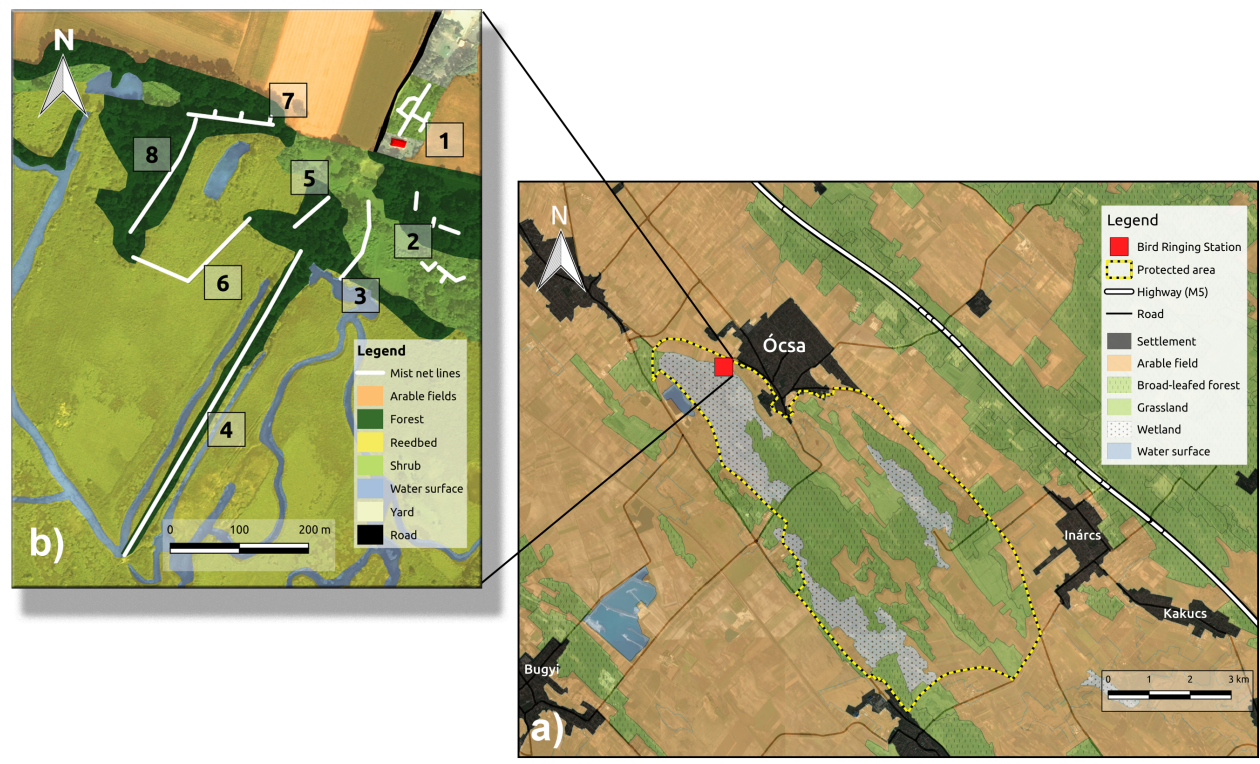

Figure 2. Location of the Ócsa Bird Ringing Station on landscape scale (a) and the habitat composition together with the position of standard mist net lines (b). The station is located on the edge of a protected wetland, that is the only natural type habitat patch in the vicinity. The area is otherwise an agricultural landscape interspersed with open-pit gravel mines and poplar plantations. The habitat surrounding the station is a mosaic of shrubs, forest type habitats and reedbeds. See text and Table 1 for detailed description of habitats surrounding mist net lines

2. ábra Az Ócsai Madárvárta elhelyezkedése (a) és az élőhely összetétel a hálóállások (b) feltüntetésével. A madárvárta egy védett terület szélén van, amely az egyetlen ilyen vizes élőhely a környéken. Mezőgazdasági területek veszik körül, amelyeken belül több kavicsbánya és telepített nyárerdők vannak. A kutatási terület vegetációja mozaikos, jellemzően bokros, fás területek és nádasok alkotják

vicinity; practically it is surrounded by arable fields, poplar plantations with several interspersed open-pit gravel mines.

\section{Climate}

Ócsa is situated in a humid continental transitional climate zone. Summers are medium warm and dry here, with relatively cold winters. The annual average temperature is $10.1^{\circ} \mathrm{C}$ (minimum ca. $-15.6{ }^{\circ} \mathrm{C}$, maximum ca. $34.1{ }^{\circ} \mathrm{C}$ ). The location is in the former glacial Danube riverbed, thus temperature values are somewhat lower than in the large scale surroundings. This is possibly one of the reasons why the glacial peat bog could survive after deglaciation. Annual precipitation is around 550-580 $\mathrm{mm}$ coming together with a ca. 2000 hours of sunshine. The direction of wind is often north-west, while the average wind speed is $2.5-3 \mathrm{~m} / \mathrm{s}$. The mean elevation is $100 \mathrm{~m}$ above sea level (Füri 2007). 


\section{Habitat}

Prior to formal protection of the site, there was intensive peat extraction from the surrounding bogs (Füri 2007). Today, the spatial structure of the habitat generally follows the succession gradient from open water to closed broad-leaved forest. However, the areas affected by open-pit extraction went under a secondary succession and were recolonized by mainly reed (Phragmites australis) and swamp sawgrass (Cladium mariscus), thus all open water surface disappeared. To reverse this process, new pits were dredged to create open water surfaces in late 2011. Simultaneously, a channel system was also created to maintain continuous water supply (Figure $2 b$ ). These works affected the vicinity of a few capture locations, however merely restored original habitat conditions. Habitats around the capture locations were further affected by secondary succession, typically increasing the height of fast growing shrubs and trees like poplars and willow species within the study period. This process had a major effect around only one mist net line (3.), where the initial dry standing heterogeneous reedbed was gradually replaced by European elderberry (Sambucus nigra), partly covered by common hop (Humulus lupulus) and more recently also by European blackberry (Rubus fruticosus).

\section{Capture methods}

Capture methods at the ringing station can be categorized to three groups; a) non-standard sporadically used methods, b) ringing at nest sites and c) standard methods. The first group of methods are predominantly used to capture raptors (cube nets, box-traps), and members of the Rallidae family (walk-in traps). The usage of these depends on season; raptor traps are only active in winter, while walk-in traps in autumn. Moreover, their usage also depends on environmental circumstances like snow cover and water level. Typically large and/or colonial breeders like White-tailed Eagles (Haliaeetus albicilla), Grey Herons (Ardea cinerea), Great Egrets (Egretta alba), Night Herons (Nycticorax nycticorax), Spoonbills (Platalea leucorodia), Black Storks (Ciconia nigra), Black-headed Gulls (Larus ridibundus), Mediterranean Gulls (Larus melanocephalus) and Common Terns (Sterna hirundo) are ringed as nestlings within the framework of national colour ringing programs. 


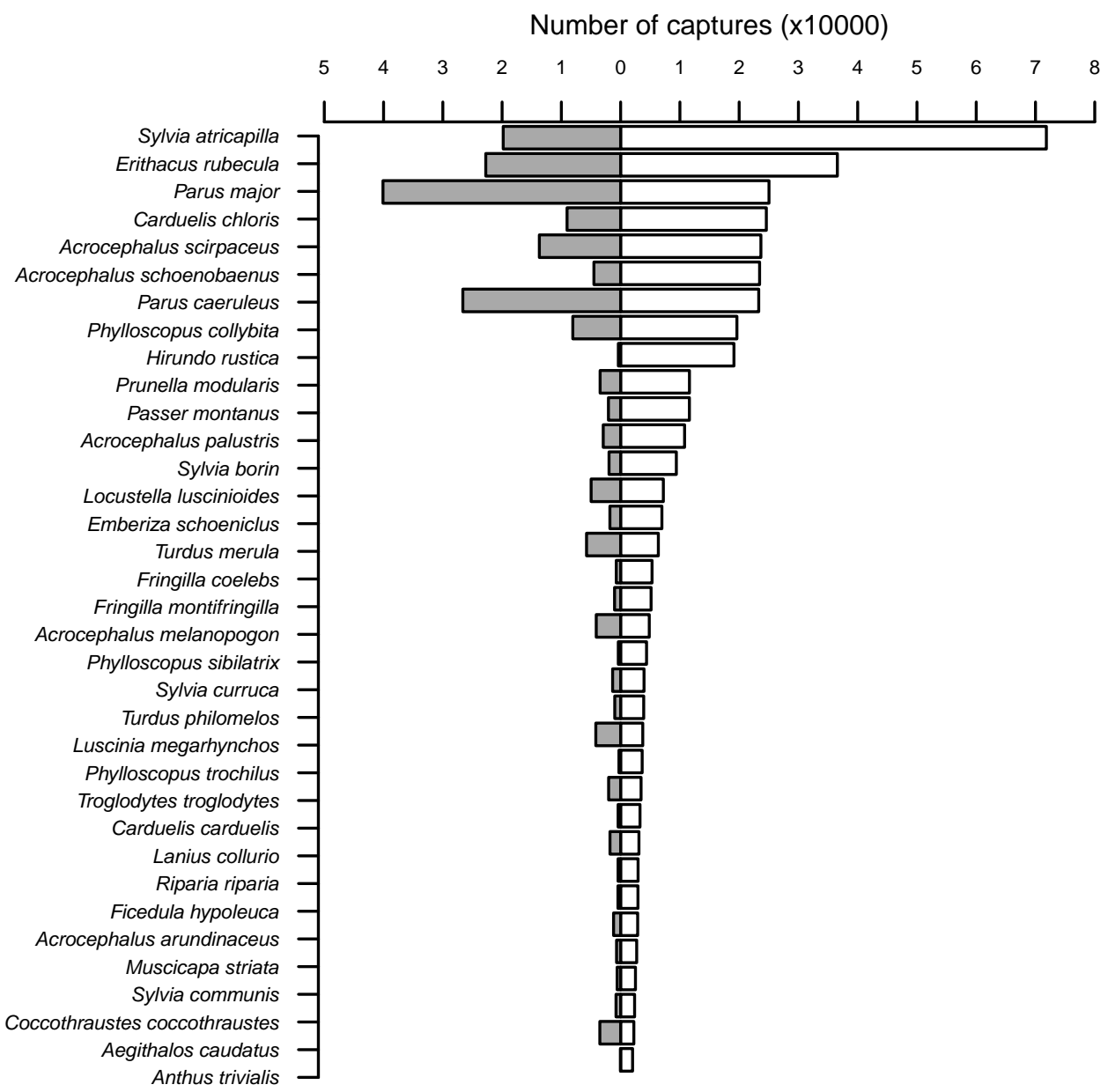

Figure 3. Capture (white bars) and recapture (grey bars) frequencies by species (1984-2015). Only the 35 most commonly ringed species are depicted

3. ábra A 35 leggyakoribb faj fogás (fehér) és visszafogás (szürke) gyakorisága 1984-2015 között

The majority of birds ringed at the station are passerines (Figure 3) captured with standard methodology that entails the usage of mist nets (dimensions: $12 \times 2.5 \mathrm{~m}$, mesh: $16 \times 16 \mathrm{~mm}$, shelves: 5 ). The locations of the mist net lines were initially chosen to sample the major habitat types in the vicinity of the station (Figure 2, Table 1). 
Table 1. Description of mist net lines

1. táblázat A hálóállások jellemzői

\begin{tabular}{|c|c|c|}
\hline $\begin{array}{l}\text { Mist net line } \\
\text { ID }\end{array}$ & Habitat description & Number of nets \\
\hline 1 & $\begin{array}{l}\text { dry reedbed scattered with European elderberry and } \\
\text { a few poplar bushes or trees }\end{array}$ & 15 \\
\hline 2 & $\begin{array}{l}\text { a patch of bush dominated by elderberry, poplar and } \\
\text { willow species (Salix spp.) }\end{array}$ & 12 \\
\hline 3 & $\begin{array}{l}\text { dry reedbed with a few elderberry and walnut (Jug- } \\
\text { lans regia), partly covered by common hop and more } \\
\text { recently also by European blackberry }\end{array}$ & 10 \\
\hline 4 & $\begin{array}{l}\text { a narrow line of poplar trees and willow bushes, sur- } \\
\text { rounded by aquatic habitat mainly reedbed }\end{array}$ & 40 \\
\hline 5 & $\begin{array}{l}\text { a forested habitat patch covered by old poplar trees, } \\
\text { more recently the blackberry is also spreading on the } \\
\text { wet soil }\end{array}$ & 5 \\
\hline 6 & $\begin{array}{l}\text { shallow standing water covered by reed, with some } \\
\text { willow bushes spreading }\end{array}$ & 17 \\
\hline 7 & $\begin{array}{l}\text { a line of Hungarian narrow-leaved ash (Fraxinus an- } \\
\text { gustifolia ssp. pannonica) trees surrounded by open } \\
\text { water, undergrowth is dominated by blackberry and } \\
\text { elderberry. }\end{array}$ & 13 \\
\hline 8 & $\begin{array}{l}\text { a patch of willow and poplar bushes and trees surroun- } \\
\text { ded by reedbed. Active since } 2001 \text { and only during } \\
\text { the Constant Effort Sites Scheme (CES) period (see } \\
\text { below for details) }\end{array}$ & 15 \\
\hline
\end{tabular}

All mist nets are opened at dawn, controlled every hour during the day, and closed at dusk. Under unfavourable weather conditions nets are controlled more frequently (ca. every half hour). In case of extreme heat, cold, or windy weather conditions all nets are closed. Tape-luring is used only in the vicinity of mist net line 1 (Figure $2 a$ ), which is relatively distant from all other mist nets (Figure $2 \mathrm{~b}$ ). Calls and songs of Acrocephalus warblers are played in August (Csörgó et al. 2008), while Sylvia/Phylloscopus Warbler and Tree Pipit calls are used through September. 


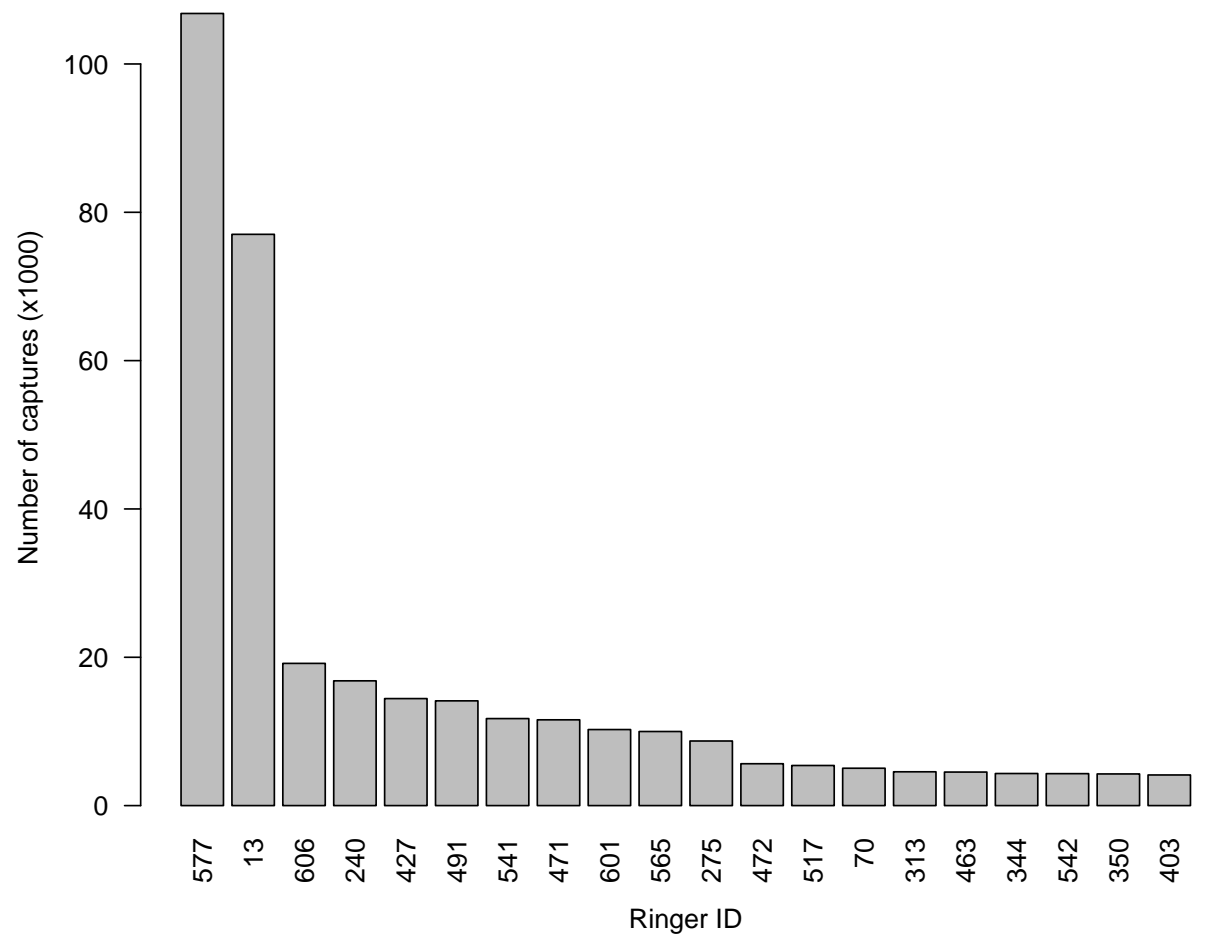

Figure 4. Number of birds handled by individual ringers in the 1984-2015 period. The majority of birds was ringed and measured by a handful of individuals

4. ábra Az egyes gyưrűzők által jelölt madarak száma 1984 és 2015 között. A gyưrúzés nagy részét kisszámú személy végezte

\section{Ringing and measuring}

A total of 110 ringers have worked at the station in the 1984-2015 period, however, $43 \%$ of birds were ringed by the first two persons and $80 \%$ by 20 ringers (Figure 4). All ringers who worked at the Ringing Station have a ringing permit (that includes a license to catch wild birds) issued by the Hungarian governmental authorities. The standard rings of the Hungarian Bird Ringing Centre (MME/BirdLife Hungary) were deployed on all birds.

Biometric measurements are taken following standardized and published methods (Szentendrey et al. 1979, Svensson 1992, EURING 2015). The following data types are recorded:

- individual ring number;

- species;

- age category;

- sex (based on plumage cues, brood patch, cloacal protuberance, or - more recently also molecular analyses of DNA samples);

- wing length (precision $\pm 0.5 \mathrm{~mm}$ ); 
- length of $3^{\text {rd }}$ primary (precision $\pm 0.5 \mathrm{~mm}$ );

- tail length (precision $\pm 0.5 \mathrm{~mm}$ );

- fat score (0-8 scale) following Kaiser (1993);

- pectoral muscle score (0-3 scale);

- body mass (precision $\pm 0.05 \mathrm{~mm}$ ) measured using Pesola springs or a digital scale;

- wing tip abrasion (0-3);

- moult (moult of covers: 0-3 scale, moult primaries, secondaries and retrices, individually) following Ginn \& Melville (1983) and Jenni \& Winkler (1994);

- date (year, month, day (precision \pm 0.5 hour));

- capture location (each bird is placed into a bag marked differently corresponding to the mist net line and the number of net; precision $\pm 6 \mathrm{~m}$ ).

\section{Data management}

Ringing data is recorded into a field notebook simultaneously with ringing. Subsequently, days or even months later, these data are entered into a data base. Then digital data are subjected to rigorous quality check by means of statistical filtering: suspicious values are individually checked (Harnos et al. 2015b). Finally, quality-checked digital data are deposited in three parallel data bases: the archive of the Ócsa Bird Ringing Station, the archive of the Hungarian Bird Ringing Centre, and the EURING data base.

\section{Capture effort and timing}

The first mist-netting trials and preliminary bird ringing activities were carried out in 1983. Subsequently, all the year round bird ringing work started from 1984 to be continued up to the present. In 2001, a building was constructed to serve as accommodation and as a working station, and simultaneously permanent working staff has been employed. These factors enabled to increase capture effort throughout the year. Each year is divided into the following 4 time periods.

Spring migration period - Starting from mid-March, and lasts until the second decade of April. Continuous daily capture throughout the period with all standard net lines.

Breeding period - Starts as soon as the spring migration period is over, and lasts until the $9^{\text {th }}$ of July. Each net line is opened once a week and the sampling follows Constant Effort Site (CES) protocols (Baillie 1986, Robinson et al. 2009).

Autumn migration period - Starts on the $10^{\text {th }}$ of July and lasts until late October to midNovember, depending on weather. Continuous daily capture throughout the period with all standard nets.

Winter feeder period - Lasts until the first day of the spring camp. Weekly ringing near bird feeders, however the dates vary depending on weather. This is the only non-standard sampling period. 


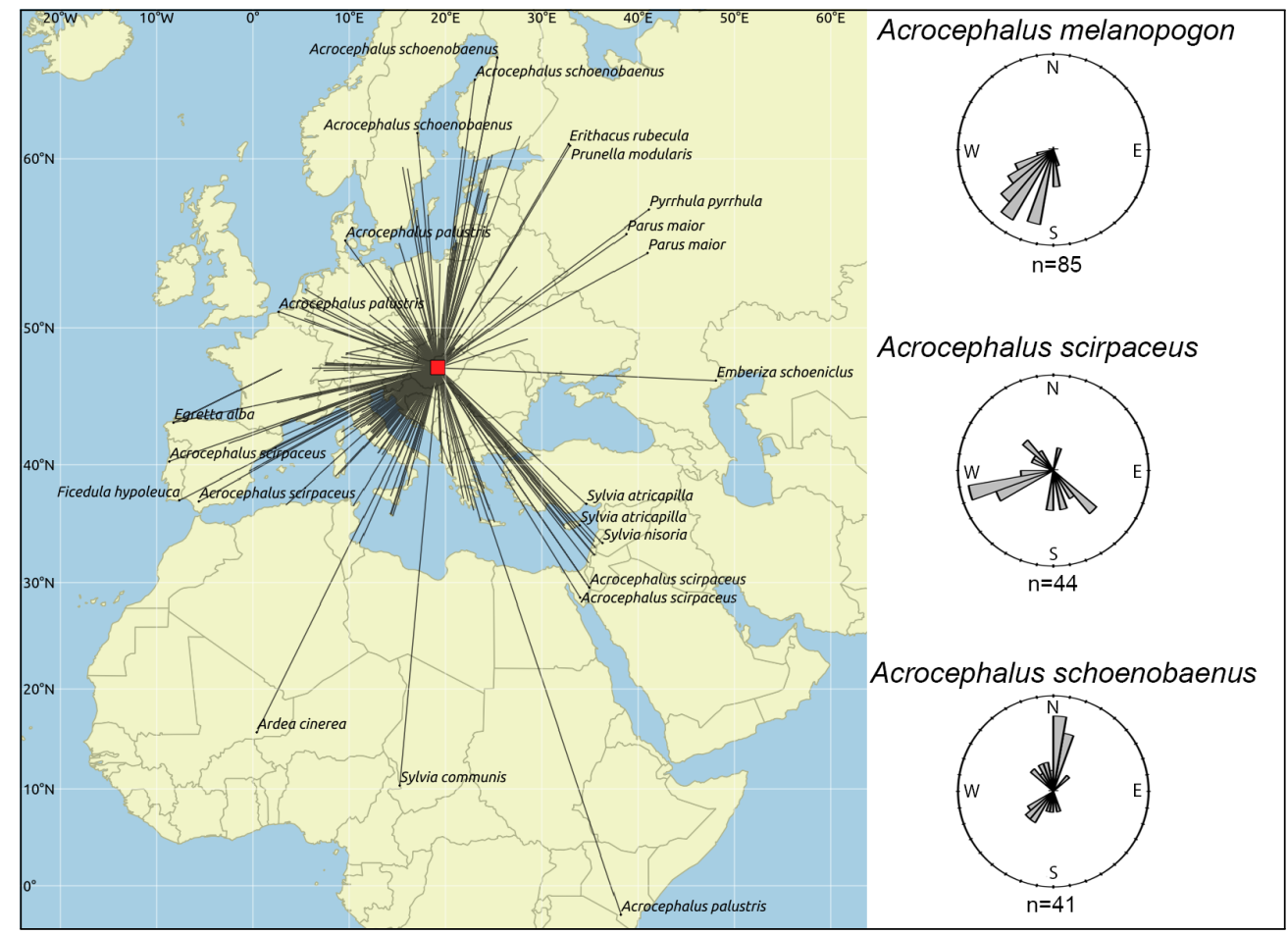

Figure 5. All foreign ring recoveries with ties to the Ócsa Bird Ringing station (i.e. recovered at the ringing station or ringed at the station and recovered elsewhere). The rose diagrams show the bearing distribution of foreign ring recoveries of three Acrocephalus warbler species with markedly different breeding and wintering distribution and/or migration strategies

5. ábra Az Ócsai Madárvártán jelölt és külföldön megkerült, illetve külföldön jelölt és itt megfogott madarak. A kördiagram 3 - eltérő költési és/vagy telelési területú, illetve vonulási stratégiájú - Acrocephalus faj egyedeinek jellemző mozgási irányait mutatja

\section{Overview of results}

The fact that every $10^{\text {th }}$ bird ringed between 1984-2015 in Hungary was handled in the Ócsa Bird Ringing Station, illustrates the national importance of study site. Indeed, the 422,862 individuals of 169 species were ringed at the station together with the 202,739 local recaptures. All of the most abundant captured species are passerines (Figure 3). Furthermore, a total of 1325 individuals were recovered over $5 \mathrm{~km}$ from the ringing station, of which 443 were foreign ring recoveries (i.e. recovered at the ringing station or ringed at the station and recovered elsewhere (Figure 5). The spatial patterns of foreign recoveries reveal that there is a considerable hiatus of birds, regardless of species, arriving from the east. This is presumably the synergistic effect of the geographical barrier effect of the Eastern Carpathians, and the lower effort in ringing activities in eastern states compared to that in northern and western countries (http://euring.org/data-and-codes/ringing-totals). 


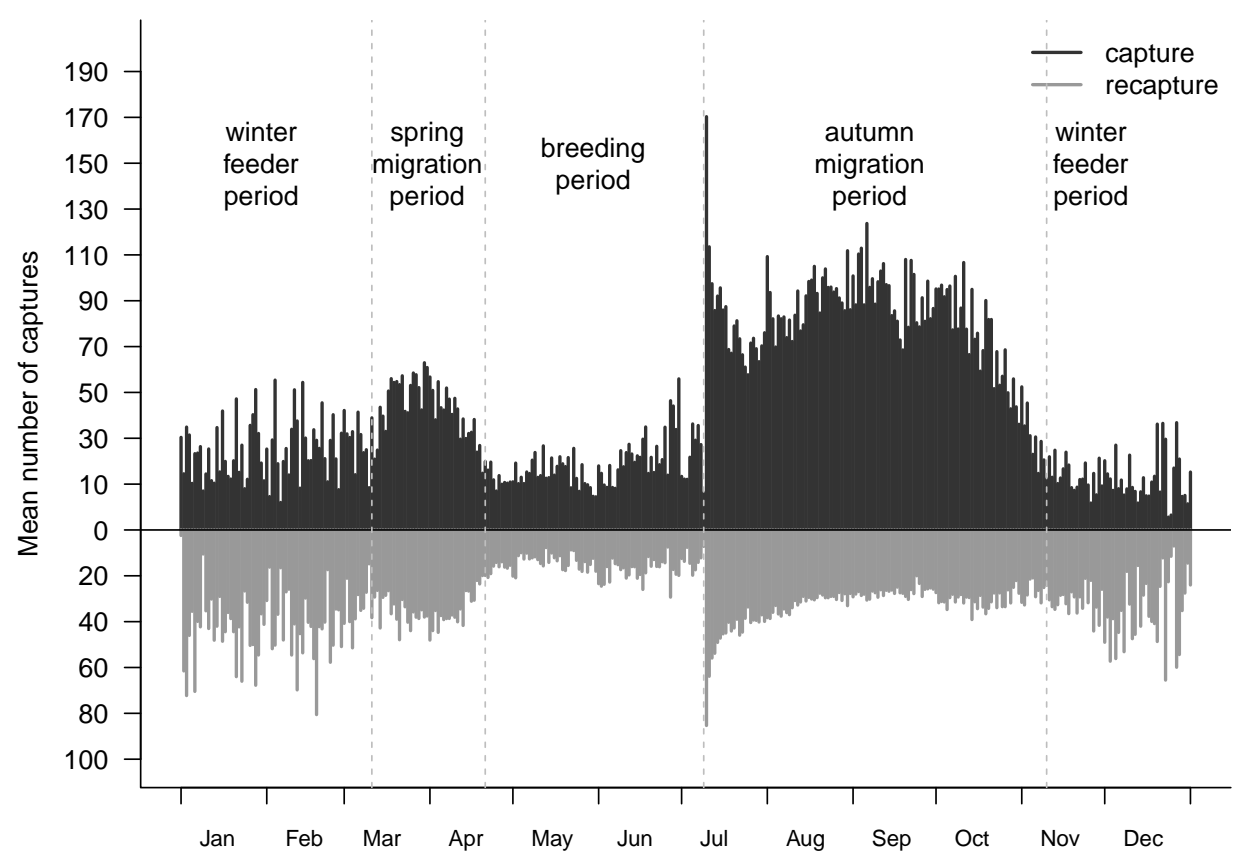

Figure 6. Mean number of total capture frequencies for each day of the year. All nets are open in spring and autumn, while standard sampling (CES protocol) is carried out in the breeding season. The difference in trapping effort causes the large abrupt increase in mean capture frequencies between at the beginning of the autumn migration period

6. ábra A napi fogás és visszafogás átlagos számai az év folyamán. A tavaszi és őszi vonulás során az összes háló ki van nyitva, a fészkelési időszak alatt a CES protokollnak megfelelően egy-egy állás csak 5-10 napon belül egyszer

The Carpathians also act as a line of demarcation to differentiate between migration strategies of trans-migrant and local breeding populations. For instance, three Acrocephalus species that all breed at the study site show markedly different recapture patterns (Figure 5). A. melanopogon, a short distance migrant with a discrete breeding distribution in the Carpathian Basin that winters in the shoreline wetlands of the Balkans and Greece, has only recaptures with southern bearing. A. scirpaceus, on the other hand, is a common reedbed specialist throughout the continent yet the recapture bearing distribution shows hardly any birds with northerly origins, indicating that the Hungarian population is isolated from that of northern European countries. However, the fact that this species is a transSaharan migrant with two distinct wintering areas (West and East Africa) can be retraced by the foreign recapture bearing distribution. Similarly to the A. scirpaceus, A. schoenobaenus has a continental breeding distribution, yet the recapture patterns show that birds caught at the Ócsa Bird Ringing Station are local breeders and passage migrants originating from northern countries, suggesting that this species is traversing the Carpathians on migration (Csörgő \& Gyurácz 2009a,b, Kovács et al. 2010, 2012). 
Considering the overall mean daily capture frequencies throughout the study period, it is apparent that the different capture periods yield considerably different bird numbers (Figure 6). In winter, when bird trapping is limited to three feeder sites and is only operating on a roughly weekly basis, capture frequencies predominantly depend on weather, hence there is large inter-annual and between-day variability in the number of ringed birds. Similar daily mean trapping rates are observable in the breeding period (CES period), however, with substantially lower between day mean variability. The transition from the CES period to the autumn migration period is striking, with approximately an order of magnitude larger daily capture yields especially early in the season. The reasons for this are two fold; first the trapping effort is drastically increased as all nets are opened on the $10^{\text {th }}$ of July, and second, both dispersing local juveniles and early migrants are present in this period. In autumn, mean capture frequencies generally have a steep and steady decrease starting from mid-October.

Inter-annual differences in capture frequencies were also substantial (Table 2, Figure 7) in the study period, however a large proportion of this variability can be explained by the increase in the number of nets since 2001 (Figure 7-8). On the other hand, the annual cumulative curve of daily captures shows that inter-annual variation does not grow steadily throughout the season. Typically annual capture totals depend on breeding period months, and winter capture rates (Figure 8).

Table 2. Descriptive statistics of yearly capture and recapture frequencies and number of species at the Ócsa Bird Ringing Station

2. táblázat Az évi fogás, visszafogás és fajszám-gyakoriságok leíró statisztikái

\begin{tabular}{|l|c|c|c|}
\hline & Captures & Recaptures & Number of species \\
\hline Minimum & 5792 & 1989 & 74 \\
\hline Median & 12974 & 6512 & 94 \\
\hline Maximum & 22902 & 10370 & 108 \\
\hline
\end{tabular}




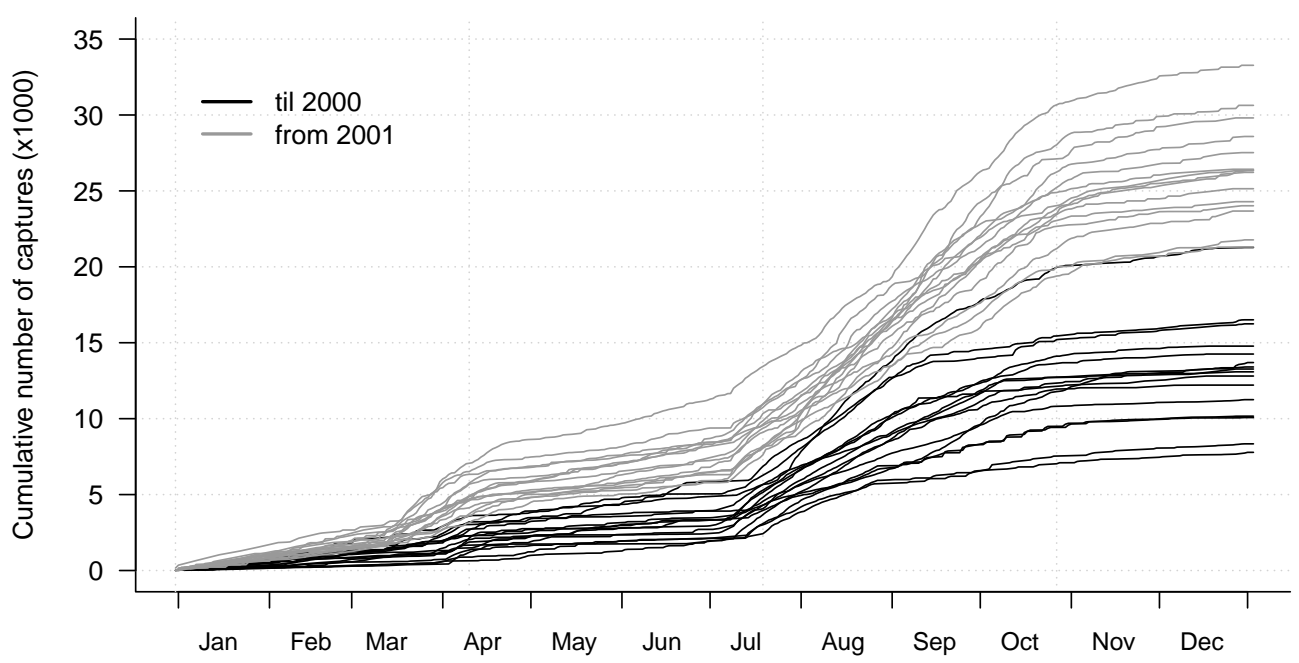

Figure 7. Annual cumulative capture frequencies in relation to day of year. There are large inter-annual differences in capture frequencies, however, since 2001 the number of nets and capture days have been increased that had an apparent effect on the number of captured birds

7. ábra Az évi fogások kummulatív görbéi. Az éves fogási mintázatok és számok nagy éves különbséget mutatnak. A nagyobb értékek jellemzően 2001-től jelentkeznek, amikortól megnőtt a hálóállások és a fogási napok száma

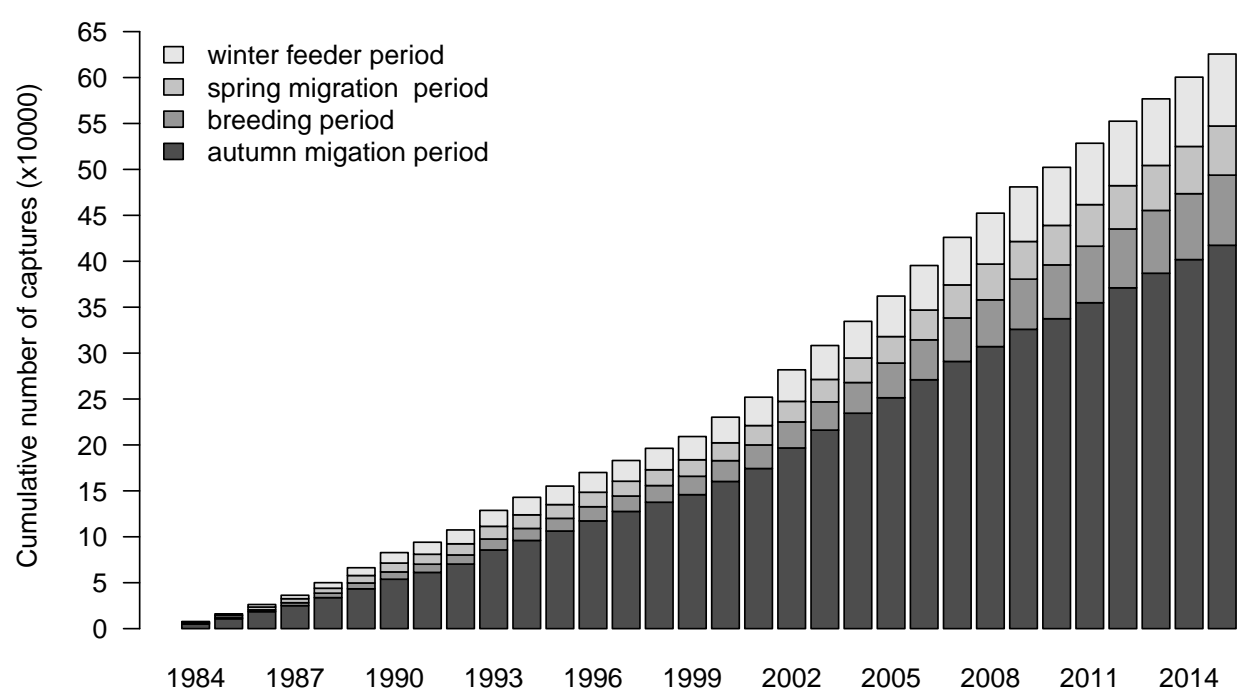

Figure 8. Cumulative capture frequencies by year through the study period. The rate of increase is larger since 2001 when the number of nets capture days were increased

8. ábra Kumulatív fogási gyakoriságok 1984-2015 között. A fogási számok 2001-től nagyobbak, nagyrészt a hálóállások és a fogási napok számának növekedése miatt 


\section{Further research projects}

From time to time, other complementary research projects that require the handling of a large number of wild birds also rely on the infrastructure and activities of the Station. These projects include studies on the distribution and ecology of viruses, ticks (Acari: Ixodidae) and lice (Insecta: Phthiraptera). Other research projects required avian blood samples to identify immunological antibodies or to carry out DNA-based sex determination of sexually monomorphic birds. Naturally, only a small portion of ringed birds were subjected to these parallel studies. Considerable emphasis is placed upon motivating BSc, MSc, and $\mathrm{PhD}$ students, as well as their tutors, to utilize data for their thesis works. Connections to the Eötvös Loránd University (Budapest) and the University of Veterinary Medicine (Budapest) have been particularly fruitful. Hypothesis-based research using data obtained from the Station covered a wide range of topics from different fields of science. Ecological studies included research on capture (see e.g. Lövei et al. 2001) and statistical (Harnos et al. 2015b, 2016a) methodology, habitat preferences (e.g. Preiszner \& Csörgó 2008, Ónodi \& Csörgó 2012, 2013), moult (e.g. Kelemen et al. 2000), social behaviour (e.g. Báldi \& Csörgő 1993, 1994b), sexual selection (e.g. Gál et al. 2012), wintering (e.g. Báldi \& Csörgő 1994c, Csörgó et al. 2001, Kovács et al. 2011, Miholcsa et al. 2016, Miholcsa \& Csörgő 2016), breeding (see e.g. Báldi \& Csörgő 1991, 1994a), and particularly migration (e.g. Csörgő \& Lövei 1995, Csörgő \& Parádi 1998, 2000, Kovács et al. 2009, Nagy et al. 2009, Gyimóthy et al. 2011a,b, Harnos \& Csörgó 2011, Csörgó \& Harnos 2011, Harnos et al. 2015c,a) studies. Furthermore, effects of weather (see e.g. Gyurácz et al. 1997, 2003) and climate change (see e.g. Miholcsa et al. 2009, Csörgó et al. 2009, Kovács et al. 2010, 2012, Harnos et al. 2015a) on avian migration phenology have been intensively studied. Finally, epidemiological studies focused on evolutionary-ecological aspects of Usutu and West Nile viruses (Bakonyi et al. 2007, 2013), ticks (Hornok et al. 2012, 2016a,b) and tick-borne infections (Hornok et al. 2013, 2014), and lice (Vas et al. 2008, 2012) infesting birds.

\section{Acknowledgments}

We thank all permanent staff, volunteers, supporters and enthusiasts that had or have had contributed to the station's work to date. This manuscript was supported by the National Scientific Research Fund of Hungary (OTKA under Grant No. 108571). 


\section{References}

Baillie, S. R. 1986. An evaluation of the Constant Effort Sites scheme: Report of the Constant Effort Sites Review Group to the Ringing Committee of the British Trust for Ornithology - Research Report 21. - British Trust for Ornithology

Bairlein, F. 1994. Manual of field methods. - European-African songbird migration network - Institut für Vogelforschung, Wilhelmshaven

Bakonyi, T., Erdélyi, K., Ursu, K., Ferenczi, E., Csörgő, T., Lussy, H., Chvala, S., Bukovsky, C., Meister, T., Weissenbock, H. \& Nowotny, N. 2007. Emergence of Usutu virus in Hungary. - Journal of Clinical Microbiology 45(12): 3870-3874. DOI: 10.1128/jcm.01390-07

Bakonyi, T., Ferenczi, E., Erdélyi, K., Kutasi, O., Csörgô, T., Seidel, B., Weissenböck, H., Brugger, K., Bán, E. \& Nowotny, N. 2013. Explosive spread of a neuroinvasive lineage 2 West Nile virus in Central Europe, 2008/2009. - Veterinary Microbiology 165(1): 61-70.

Báldi, A. \& Csörgó, T. 1991. The effect of nestboxes on bird species diversity and the breeding density of the Great Tit (Parus major L., 1758) in different habitats. - Aquila 98: 141-146. epa.niif.hu/01600/ 01603/00080/pdf/Aquila_EPA-01603_1993_201-209.pdf

Báldi, A. \& Csörgő, T. 1993. Social dominance in the resident part of a Great Tit (Parus major) population in winter. - Ornis Hungarica 3: 7-12.

Báldi, A. \& Csörgő, T. 1994a Breeding site fidelity of Great Tits (Parus major) in a Central-European alder forest. - Ornis Hungarica 4: 1-2.

Báldi, A. \& Csörgő, T. 1994b Influence of age and dominance status of male and female Great Tits on laying date, clutch size and egg dimensions. - Acta Zoologica Academiae Scientiarum Hungaricae 40(2): 99-107. http://actazool.nhmus.hu/ac40_2.html

Báldi, A. \& Csörgő, T. 1994c Roosting site fidelity of Great Tits (Parus major) during winter. - Acta Zoologica Academiae Scientiarum Hungaricae 40(4): 359-367. http://actazool.nhmus.hu/ac40_4.html

Busse, P. 1974. Metody biometryczne [Biometrical methods]. - Notatki Ornitologiczne 15: 115-126. (in Polish)

Busse, P. \& Kania, W. 1970. Akcja Baltycka. Sekcja Polska 1961-1967 Metod pracy [Actio Baltica 1961-1967 working methods]. - Acta Ornithologica 12: 231-267. (in Polish)

Csörgő, T. \& Gyurácz, J. 2009a Cserregő nádiposzáta [Eurasian Reed Warbler]. - In: Csörgő, T., Karcza, Zs., Halmos, G., Magyar, G., Gyurácz, J., Szép, T., Bankovics, A., Schmidt, A. \& Schmidt, E. (eds.) Magyar madárvonulási atlasz [Hungarian Bird Migration Atlas]. - Kossuth Kiadó Zrt., Budapest, pp. 489-493. (in Hungarian with English Summary)

Csörgő, T. \& Gyurácz, J. 2009b Foltos nádiposzáta [Sedge Warbler]. - In: Csörgó, T., Karcza, Zs., Halmos, G., Magyar, G., Gyurácz, J., Szép, T., Bankovics, A., Schmidt, A. \& Schmidt, E. (eds.) Magyar madárvonulási atlasz [Hungarian Bird Migration Atlas]. - Kossuth Kiadó Zrt., Budapest, pp. 483-488. (in Hungarian with English Summary)

Csörgő, T., Halmos, G. \& Lóránt, M. 2008. Mi a különbség a standard módszerekkel és a mesterséges hívóhang használatával fogott nádiposzáták között? [Differences between Reed Warblers cought by standard methods and artificial calls]. - Ornis Hungarica 15-16: 77-78. http://ornis.hu/articles/ OrnisHungarica_vol15-16_p77-78.pdf, (in Hungarian)

Csörgő, T. \& Harnos, A. 2011. A csilpcsalpfüzike (Phylloscopus collybita) vonulásának változása 23 év alatt [Change of Chiffchaff's (Phylloscopus collybita) migration during 23 years]. - Ornis Hungarica 19(1-2): 53-63. http://ornis.hu/articles/OrnisHungarica_vol19_p53-63.pdf, (in Hungarian with English Summary)

Csörgő, T., Harnos, A., Kovács, Sz.. \& Nagy, K. 2009. A klímaváltozás hatásainak vizsgálata hosszútávú madárgyuurúzési adatsorok elemzésével [Study of the impacts of climate change using long-term bird ringing data]. - Természetvédelmi Közlemények 15: 1-12. (in Hungarian with English Summary)

Csörgő, T. \& Lövei, G. 1995. Migration and recurrence of the Thrush Nightingale Luscinia luscinia at a stopover site in Central Hungary. - Ardeola 42: 57-68. 
Csörgó, T., Móra, V. \& Miklay, Gy. 2001. Autumn migration and wintering of Dunnock (Prunella modularis) in Hungary. - Ring 23(1-2): 99-107. http://www.wbwp-fund.eu/ring/pdf/23-1-2/csor.pdf

Csörgó, T. \& Parádi, I. 1998. Migration of Red-backed Shrike (Lanius collurio) in the Carpathian Basin. Proceeding of the $2^{\text {nd }}$ International Shrike Symposium in IBCE Tech. Publ. 6: 1-5.

Csörgő, T. \& Parádi, I. 2000. A tövisszúró gébics (Lanius collurio) ôszi vonulása magyarországon [Migration of the Red-backed Shrike (Lanius collurio) in Hungary]. - Ornis Hungarica 10: 153162. http://www.ornis.hu/articles/OrnisHungarica_vol10_p153-161.djvu, (in Hungarian with English Summary)

EURING 2015. The EURING Exchange Code 2000 Plus. - The European Union for Bird Ringing, Thetford, U.K. http://www.euring.org/data_and_codes/euring_code_list/index.html

Füri, A. 2007. Ócsai Tájvédelmi Körzet [Ócsa Protected Landscape Area]. - In: Tardy, J. (ed.) A magyarországi vadvizek világa. Hazánk ramsari területei [The world of natural waters in Hungary: Ramsar sites]. - Alexandra, Pécs, pp. 134-141.

Gál, E., Csörgó, T. \& Vas, Z. 2012. Relationship between sexual signals and louse (Insecta: Phthiraptera) infestation of breeding and migrating Barn Swallows (Hirundo rustica) in Hungary. - Ornis Hungarica 20(1): 37-43. DOI: 10.2478/orhu-2013-0003

Ginn, H. \& Melville, D. 1983. Moult in birds. BTO Guide 19. - British Trust for Ornithology, Tring

Gyimóthy, Zs., Gyurácz, J., Bank, L., Bánhidi, P., Farkas, R., Németh, Á. \& Csörgő. 2011a Wing-length, body mass and fat reserves of Robins (Erithacus rubecula) during autumn migration in Hungary. Acta Zoologica Academiae Scientiarum Hungaricae 57(2): 203-218. http://actazool.nhmus.hu/57/2/ azh_57_2_Gyimothy.pdf

Gyimóthy, Zs., Gyurácz, J., Bank, L., Bánhidi, P., Farkas, R., Németh, Á. \& Csörgő, T. 2011b Autumn migration of Robins (Erithacus rubecula) in Hungary. - Biologia 66(3). DOI: 10.2478/s11756-0110039-9

Gyurácz, J., Horváth, G., Csörgő, T., Bank, L. \& Palkó, S. 2003. Influence of macrosynoptic weather situation on the autumn migration of birds in Hungary. - Ring 25(1-2): 17-36.

Gyurácz, J., Károssy, Cs. \& Csörgó, T. 1997. The autumn migration of Sedge Warblers in relation to weather conditions. - Weather 52(5): 149-154. DOI: 10.1002/j.1477-8696.1997.tb06296.x

Harnos, A., Ágh, N., Kovács, Sz., Lang, Zs. \& Csörgó, T. 2015a Increasing protandry in the spring migration of the Pied Flycatcher (Ficedula hypoleuca) in Central Europe. - Journal of Ornithology 156(2): 543-546. DOI: 10.1007/s10336-014-1148-3

Harnos, A., Csörgó, T. \& Fehérvári, P. 2016a Hitchhikers' guide to analysing bird ringing data. Part 2. Ornis Hungarica 24(1): 172-181. DOI: 10.1515/orhu-2016-0010

Harnos, A. \& Csörgő, T. 2011. Ivarmeghatározás biometriai adatok alapján - esettanulmány a csilpcsalpfüzikére [Sex determination based on biometrical data - a case study for the Chiffchaffs]. - Ornis Hungarica 19(1-2): 40-52. http://ornis.hu/articles/OrnisHungarica_vol19_p40-52.pdf, (in Hungarian with English Summary)

Harnos, A., Fehérvári, P. \& Csörgó, T. 2015b Hitchhikers' guide to analysing bird ringing data. Part 1. Ornis Hungarica 23(2): 163-188. DOI: 10.1515/orhu-2015-0018

Harnos, A., Fehérvári, P., Piross, I. S., Ágh, N., Karcza, Zs., Konrád, K. \& Csörgő, T. 2016b Exploratory analyses of migration timing and morphometrics of the Dunnock (Prunella modularis). - Ornis Hungarica 24(2): 127-144. DOI: 10.1515/orhu-2016-0020

Harnos, A., Fehérvári, P., Piross, I. S., Karcza, Zs., Ágh, N., Kovács, Sz. \& Csörgő., T. 2016c Exploratory analyses of migration timing and morphometrics of the Pied Flycatcher (Ficedula hypoleuca). - Ornis Hungarica 24(2): 109-126. DOI: 10.1515/orhu-2016-0019

Harnos, A., Lang, Zs., Fehérvári, P. \& Csörgó, T. 2015c Sex and age dependent migration phenology of the Pied Flycatcher in a stopover site in the Carpathian Basin. - Ornis Hungarica 23(2): 10-19. DOI: 10.1515/orhu-2015-0010 
Hornok, S., Csörgó, T., de la Fuente, J., Gyuranecz, M., Privigyei, Cs., Meli, M. L., Kreizinger, Zs., Gönczi, E., de Mera, I. G. F. \& Hofmann-Lehmann, R. 2013. Synanthropic birds associated with high prevalence of tick-borne Rickettsiae and with the first detection of Rickettsia aeschlimannii in Hungary. - Vector-Borne and Zoonotic Diseases 13(2): 77-83. DOI: 10.1089/vbz.2012.1032

Hornok, S., Flaisz, B., Takács, N., Kontschán, J., Csörgő, T., Csipak, Á., Jaksa, B. R. \& Kováts, D. 2016a Bird ticks in Hungary reflect western, southern, eastern flyway connections and two genetic lineages of Ixodes frontalis and Haemaphysalis concinna. - Parasites \& Vectors 9: 101. DOI: 10.1186/s13071016-1365-0

Hornok, S., Karcza, Zs. \& Csörgő, T. 2012. Birds as disseminators of ixodid ticks and tick-borne pathogens: note on the relevance to migratory routes. - Ornis Hungarica 20(2): 86-89. DOI: 10.2478/orhu2013-0010

Hornok, S., Kováts, D., Csörgő, T., Meli, M. L., Gönczi, E., Hadnagy, Zs., Takács, N., Farkas, R. \& Hofmann-Lehmann, R. 2014. Birds as potential reservoirs of tick-borne pathogens: first evidence of bacteraemia with Rickettsia helvetica. - Parasites \& Vectors 7(1): 128-135. DOI: 10.1186/1756-33057-128

Hornok, S., Kováts, D., Flaisz, B., Csörgő, T., Könczöl, Á., Balogh, Gy. T., Csorba, A. \& Hunyadi, A. 2016b An unexpected advantage of insectivorism: insect moulting hormones ingested by song birds affect their ticks. - Scientific Reports 6: 23390. DOI: 10.1038/srep23390

Jenni, L. \& Winkler, R. 1994. Moulting and ageing of European passerines. - Academic Press, New York

Kaiser, A. 1993. A new multi-category classification of subcutaneous fat deposits of songbirds. - Journal of Field Ornithology 64: 246-255.

Karcza, Zs. \& Magyar, G. 2009. A madárgyúrúzés története [The history of bird ringing]. - In: Csörgő, T., Karcza, Zs., Halmos, G., Magyar, G., Gyurácz, J., Szép, T., Bankovics, A., Schmidt, A. \& Schmidt, E. (eds.) Magyar madárvonulási atlasz [Hungarian Bird Migration Atlas]. - Kossuth Kiadó Zrt., Budapest, pp. 48-52. (in Hungarian with English Summary)

Kelemen, A. M., Halmos, G. \& Csörgő, T. 2000. The postnuptial moult of Savi’s Warbler (Locustella luscinioides). - Ornis Hungarica 10: 99-110. http://ornis.hu/articles/OrnisHungarica_vol10_p99-110. pdf, (in Hungarian with English Summary)

Kovács, Sz., Csörgő, T., Harnos, A., Fehérvári, P. \& Nagy, K. 2010. Change in migration phenology and biometrics of two conspecific Sylvia species in Hungary. - Journal of Ornithology 152(2): 365-373. DOI: $10.1007 / \mathrm{s} 10336-010-0596-7$

Kovács, Sz., Csörgő, T., Harnos, A. \& Nagy, K. 2009. A kerti poszáta (Sylvia borin) vonulási fenológiájának változása ócsán az elmúlt 24 év során [Change in migration phenology of Garden Warbler (Sylvia borin) at the Ócsa Bird Ringing Station between 1984-2007]. - Természetvédelmi Közlemények 15: 422-433. http://www.mbt-biologia.hu/gen/pro/mod/let/let_fajl_kiiras.php?i_faj_azo=712\& b_megnyitas=igaz, (in Hungarian with English Summary)

Kovács, Sz., Csörgő, T., Harnos, A. \& Nagy, K. 2011. A zöldike (Carduelis chloris) előfordulásának alakulása Ócsán 1984-2007 közötti teleken [Population fluctuations in winter of the Green Finch (Carduelis chloris) at Ócsa between 1984-2007]. - Ornis Hungarica 19(1-2): 75-84. http://ornis.hu/ articles/OrnisHungarica_vol19_p75-84.pdf, (in Hungarian with English Summary)

Kovács, Sz., Fehérvári, P., Nagy, K., Harnos, A. \& Csörgő, T. 2012. Changes in migration phenology and biometrical traits of Reed, Marsh and Sedge Warblers. - Central European Journal of Biology 7(1): 115-125. DOI: $10.2478 / \mathrm{s} 11535-011-0101-1$

Lövei, G., Csörgő, T. \& Miklay, Gy. 2001. Capture efficiency of small birds by mist nets. - Ornis Hungarica 11: 19-25. http://ornis.hu/articles/OrnisHungarica_vol11_p19-25.pdf

Miholcsa, T. \& Csörgő, T. 2016. Testing wintering area identification efficiency with NDVI and survival of Marsh Warblers Acrocephalus palustris. - North-Western Journal of Zoology 12(2): 325-335. biozoojournals.ro/nwjz/content/v12n2/nwjz_e161609_Miholcsa.pdf 
Miholcsa, T., Harnos, A. \& Csörgő, T. 2016. Using remote-sensing to identify wintering and moulting areas of a long-distance migrant: Marsh Warbler (Acrocephalus palustris). - Applied Ecology and Environmental Research 14(1): 265-275. DOI: $10.15666 /$ aeer/1401 265275

Miholcsa, T., Tóth, A. \& Csörgő, T. 2009. Change of timing of autumn migration in Acrocephalus and Locustella genus. - Acta Zoologica Academiae Scientiarum Hungaricae 55(2): 175-185. http: //actazool.nhmus.hu/55/2/Azh55_2_Miholcsa.pdf

Nagy, K., Csörgő, T., Harnos, A. \& Kovács, Sz. 2009. A cserregő és az énekes nádiposzáta (Acrocephalus scirpaceus, A. palustris) vonulásának fenológiai változásai [Changes in the migration phenology of Reed and Marsh Warbler (Acrocephalus scirpaceus, A. palustris)]. - Természetvédelmi Közlemények 15: 422-433. http://www.mbt-biologia.hu/gen/pro/mod/let/let_fajl_kiiras.php?i_faj_azo=713\& b_megnyitas=igaz, (in Hungarian with English Summary)

Ónodi, G. \& Csörgó, T. 2012. A nagy fakopáncs (Dendrocopos major Linnaeus, 1758) élóhely preferenciája nagy mozaikosságú élőhelyen [The habitat preference of the Great-spotted Woodpecker (Dendrocopos major Linnaeus, 1758) in a mosaic habitat]. - Természetvédelmi Közlemények 18: 404-414. http: //www.mbt-biologia.hu/gen/pro/mod/let/let_fajl_kiiras.php?i_faj_azo=793\&b_megnyitas=igaz, (in Hungarian with English Summary)

Ónodi, G. \& Csörgó, T. 2013. Relationship between vegetation structure and abundance of Greatspotted Woodpeckers (Dendrocopos major) in a mosaic habitat. - Ornis Hungarica 21(1): 1-11. DOI: 10.2478/orhu-2013-0011

Preiszner, B. \& Csörgő, T. 2008. Habitat preference of Sylviidae warblers in a fragmented wetland. Acta Zoologica Academiae Scientiarum Hungaricae 54(Suppl. 1): 111-122. http://actazool.nhmus.hu/ 54/Suppl1/azh54_S1_Preiszner.pdf

Robinson, R. A., Julliard, R. \& Saracco, J. F. 2009. Constant effort: Studying avian population processes using standardised ringing. - Ringing \& Migration 24(3): 199-204. DOI: $10.1080 / 03078698.2009 .9674392$

Svensson, L. 1992. Identification Guide to European Passerines - Ugga, Stockholm, $4^{\text {th }}$ ed., pp. 227-231.

Szentendrey, G., Lövei, G. \& Kállay, Gy. 1979. Az Actio Hungarica madárgyưrűző tábor mérési módszerei [Measuring methods in the bird ringing camps of Actio Hungarica]. - Állattani Közlemények 66: 161-166. (in Hungarian)

Vas, Z., Csörgő, T., Møller, A. P. \& Rózsa, L. 2008. The feather holes on the Barn Swallow Hirundo rustica and other small passerines are probably caused by Brueelia spp. lice. - Journal of Parasitology 94(6): 1438-1440. DOI: 10.1645/GE-1542.1

Vas, Z., Privigyei, Cs., Prohászka, V. J., Csörgô, T. \& Rózsa, L. 2012. New species and host association records for the Hungarian avian louse fauna (Insecta: Phthiraptera). - Ornis Hungarica 20(1): 44-49. DOI: 10.2478/orhu-2013-0004

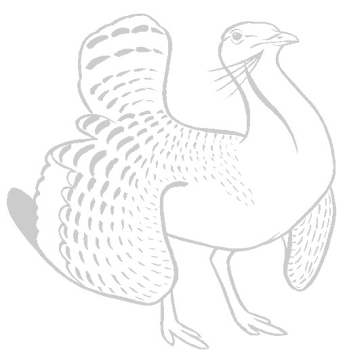

